\title{
Managing the Transition from Primary School Mathematics to Secondary School Mathematics: Teachers' and Learners' Perspectives
}

\author{
Mutodi Paul \\ Department of Maths, Science and Technology, University of Limpopo (Turf loop Campus) \\ Private Bag X1106, Sovenga, 0727 \\ Email: paul.mutodi@ul.ac.za
}

Doi:10.5901/mjss.2014.v5n25p205

\begin{abstract}
The transition into high school is a critical point in the educational pipeline, and eighth grade can be characterised as one of its leakiest junctures. The study investigated the challenges experienced by students in mathematics during the transition from primary school (Grade 7) to secondary school (Grade 8). The sample for the study consists of 60 learners randomly selected from four secondary schools in Sekhukhune district, Limpopo Province, South Africa. Fifteen (15) students were randomly selected from each of the participating schools. Purposive sampling was used to select 10 grade 8 mathematics teachers at the selected schools. Data was collected from the participants using questionnaires. The research focused on classroom practices and curriculum continuity, students' preparedness for the transition, and the kinds of support provided for the students by receiving schools. The research also investigated students' experiences such as levels of challenge of mathematical concepts, performance, pace, time pressures, new environment and the discontinuities they experienced in their learning contexts. $T$ tests and Anova were used to test for gender and backgrounds differences in terms of students' experiences. The results show that the most significant changes affecting the students during the transition to secondary school were: differences in pedagogy from primary to secondary; changes in mathematics curriculum content; and a decrease in student performance. The insights about the various transition challenges in a student's education should inform teachers and other stakeholders to make necessary precautions to ensure a smooth transaction that support students' academic performance.
\end{abstract}

Keywords: transition, perspectives, pedagogy, mathematics content, achievement, secondary school.

\section{Introduction and Background to the Study}

The transition to primary school is one of the greatest challenges in the educational history of learners. These challenges can have detrimental effects on the pupils' academic profiles (Darlaston-Jones, Cohen, Drew \&Young, 2001). The challenges present academic obstacles in students' educational careers (Skovsmose \& Valero, 2002; Chauraya, 2007). The transition also negatively affects students' academic performance and their general sense of well-being (Zeedyk, Gallacher, Henderson, Hope, Husband \& Lindsay, 2003; West, Sweeting \&Young, 2010). A number of studies have noted that disaffection and under-achievement in secondary schooling may have their beginnings during transition (Jha, 2006; Powell, 2006). An immediate consequence of these challenges that has been identified by researchers is pupils' performance loss (Evangelou, 2008). Furthermore, Mackenzie (2012) noted that the transition can also be a stressful event for most students. The transition is also characterised by a dip in attainment, while some children engage less well with class teaching and school work (Galton, Gray, and Ruddock, 2000). Rammala (2009) also noted that long-lasting under-achievement in some South African schools is attributed to the nature of teaching and learning during the transition years.

Bangser (2008) blamed secondary school teachers for failing to make use of, or refer to pupils' previous mathematics learning experiences. Students' academic profiles supplied by primary schools on pupils' previous attainments are rarely used effectively to plan curriculum experiences in the secondary school (Jindal-Snape \& Foggie, 2006; Griebel \&Beranger, 2006). This makes it difficult for teachers to respond to the individual learning needs of pupils that have arisen because of different prior experiences and achievements. This leads to dips in academic achievement, decreased self-esteem, and increased mathematical anxiety. Galton, et al. (2003) recognized the transition period as a stumbling point for students, particularly those at risk. Effective support around transition can help to counterbalance some of that risk and prevent later problems, including progressive disengagement from school.

The transition requires students to make ongoing adjustments over quite some time: for example, when encountering the different subject requirements and expectations of their various teachers, when managing multiple 
homework and other deadlines. The biggest danger for this period is students' increased tendency to be more negative about school, their relationships with teachers, and teaching and learning. Tilleczek (2007) noted that the increase in content depth and adaptations to new pedagogies presents challenges which may lead to achievement loss. The transition period is also characterised by the development of negative attitudes towards mathematics. Students' performance scores tend to show a declined trend on transfer to secondary school and thereon from year to year, with girls having lower scores. Most researchers attribute the dips at transfer to the failure of the actual lessons to meet the high expectations that pupils bring with them at transfer (Evangelou, 2008; Galton, 2009).

Another challenge experienced by students during transition to high school is failure to adapt to the secondary school curriculum. Transition can be difficult for some students as they are required to adapt into a new environment and learning styles that is different from what they have learned during their previous years in primary school. Many students experience significant changes in the teaching and learning practices. A substantial review of the research literature documents the fact that the transition into high school is marked by increased disengagement and declining motivation among students, which in turn, predict subsequent school failure and dropout (Kay \& Knaack, 2008). Furthermore the transition phase also coincides with the time when students are experiencing physiological, psychological and social changes associated with adolescence (Moroney \& Stocks, 2005).

A common trend emerging from a number of researchers is an overwhelmingly smaller percentage of students pursuing the study of mathematics at upper secondary level and beyond Nardi \& Steward, 2003; West, 2010). The choice not to pursue mathematics has been seriously influenced by students' attitudes towards and performance in mathematics, in turn deeply shaped by school mathematical experiences and the teaching they experienced in school (Nardi \& Steward, 2003). Disinterest and negative attitudes towards mathematics generated by certain pedagogical approaches seems strongly linked with underachievement (Attard, 2011). Researchers have noted that the factors that influence students' engagement in mathematics occur both outside and within the school, and outside and within the mathematics classroom (Marzano, Pickering \& Heflebower, 2011). This study is however limited to those occur within the mathematics classroom that can be observed and recorded by teachers during engagement with the learners.

Although transition to high school can play a major role in influencing engagement, there are additional factors specific to the learning and teaching of mathematics itself that play a critical role. Factors such as curriculum, pedagogy, assessment strategies, social interactions and students' relationships with others influence engagement. Together with transition, these factors are a cause for concern. Wylie, Hodgen \& Ferral (2006) observed that many grade 7 students expect grade 8 work to be harder, presenting a challenge to some, and anxiety and concern for others. A study conducted by Ganeson (2006) on students' perceptions of the transition to secondary school by found that academic work during their first year of secondary school was not harder compared to their final primary year, yet they still had difficulty adjusting to the new academic environment. Mizelle and Irvin (2000) noted that some pupils' expectation of harder mathematics at secondary school threatened their self-image as competent learners. They found that, for many pupils, their confidence in themselves as high achievers suddenly appeared fragile as transition approached. However McGee, Ward, Gibbons \& Harlow (2003) argued that some level of achievement loss during the transition to secondary is unavoidable.

Another common feature that characterise the transition period is mathematical anxiety. Previous research has shown that most students making the transition have considerable anxieties about the changes (Anderson, Jacobs, Schramm \& Splittgerbe, 2000; Lucey and Reay, 2000; Zeedyk et al, 2003). Hawk and Hill (2004 noted that most children adjust to the new school environment within six months, and many regain losses in performance by their second year. However, Lucey and Reay (2000) saw the positive functions of anxiety as a part of the developmental process; an integral and necessary force in transitional states, particularly those connected to changes which impact powerfully on children's construction of 'self'. They argued that in order to gain freedom and autonomy from adult regulation one must be ready to relinquish some measure of protection which that regulation affords. They do caution, however, that although anxiety can be considered as central to the development of effective coping strategies, there is a level beyond which anxiety becomes counterproductive to the process of moving forward.

Transition between key academic levels is a potential threat to students' academic progress. If such a transition is not well-managed, it can lead to multiple consequences such as loss in performance, disengagement, disinterest and negative attitudes towards key subjects such as mathematics. The aim of this study is to gain insights into students' experiences of mathematics teaching and learning during the transition from primary to secondary school. There is a gap in research with a lack of longitudinal studies set within the South African context. There is limited research on teachers' and students' perspectives on mathematics teaching and learning during the transition phase. Therefore the present study seeks to address the current gaps in research and explore students' perceptions of teaching and learning in mathematics, identifying pedagogies that help sustain engagement, fostering continued study and enjoyment of 
mathematics.

\section{Theoretical Framework}

The research was conducted within the theoretical framework of Dewey's (1966) theory on continuity of experience in education. The theory was developed further by Fishman and McCarthy (1998). According to Dewey, the knowledge that the student has acquired in one situation becomes an instrument of understanding and dealing effectively with the situations which follow. According to this theory the process of transfer can be looked at through the lens of two competing theoretical perspectives: one favouring continuity, the other discontinuity and argues that a balance needs to be struck between the two. These two theories have dominated the debate about transfer. The first of these might be described as a 'matching' theory, whereby the transfer works best when the school environment fits the young adolescents' perceived psychological needs and dispositions (Eccles and Midgley, 1989;Galton, Steward and ,2009). These researchers call it an environment fit theory. According to this theory, a poor fit results in dips in both pupils' attitudes and also their attainment. The theory places a lot of emphasis on the degree of continuity at transfer, particularly curriculum continuity, including both subject matter and teaching methods (Gorwood, 1986). Many discontinuities could be predicted: physical location, peer and carer relationships, social and academic expectations and levels of control. The goal of a successful transition might be constructed as individual students and pupils coming to terms with such discontinuities and learning to manage those (Fabian, 2000). Other frameworks that have been used to explain the transition from primary to secondary school include the ecological theory (La Paro, Pianta \& Cox, 2000), socio-cultural perspective (Petriwskyj, Thorpe \& Tayler, 2005). The ecological theory, places individuals in the centre of interactive systems, which represent proximal and distal relationships and processes on an individual's life as well as the historical and political. According to Tobbell, O'Donnell \& Zammit (2010) the ecological theory provides a powerful representation of the transition experience. In terms of transition the model provides an overview of the many levels of change which occur. In proximal processes face to face relationships change, new teachers, new colleagues and new friends enter the student's life. The socio-cultural perspective emphasise the need to understand the context of school for each child.

Researchers identified three major discontinuities as a result of transition: curriculum shifts (Tobbell, 2005), shifts from multiple teaching strategies in junior schools to restricted teaching approaches in senior schools (Galton and Pell, 2002; Tobbell, 2005) and environmental discontinuities such as changing classrooms every lesson, lack of space to play, no personal space (Galton and Comber, 2003; Tobbell, 2005). In theory secondary schools are expected to continue from where primary schools stop, so the mathematics work moves from simple arithmetic to more challenging and complex concepts.

\section{Research Design and Methodology}

\subsection{Approach}

This study is explorative and descriptive and uses a quantitative design to explore students' experiences and challenges in mathematics during the transition from primary to secondary school. The study also explores how teachers assist students to handle the transition. The researcher observed students' drop in performance during the transition from primary to secondary school and seeks to understand more about it and lay the groundwork that will lead to future studies, or to determine if the observed trend can be explained by currently theories about phenomena.

\subsection{Research instrument and description participants}

A questionnaire was used to solicit students' experiences as well as how educators help to adapt to the new curriculum. Eighty (80) questionnaires were randomly distributed to grade 8 students doing mathematics at selected secondary schools in Limpopo province of South Africa. Four schools participated in the study. Purposive sampling was used to select educators offering mathematics to grade 8 students at the selected schools. Students were asked to indicate their experiences of the transition according to the following alternatives: $1=$ Disagree; ......5=Agree. It was found that $60(75 \%)$ questionnaires contained valid responses. These were analysed using the Statistical Package for the Social Sciences (SPSS), version 22. Ten (10) Grade 8 mathematics teachers also responded to a separate questionnaire which sort to solicit information pertaining to how they perceive transition phase in the teaching and learning of mathematics. 


\section{Reliability and Validity}

In order to check whether the questions in the questionnaire all reliably measure the same latent variable (transition perspectives); a Cronbach's alpha was run on a sample size of 60 grade 8 learners. The Cronbach alpha correlation coefficient for the 33 -item questionnaire was found to be 0.79 suggesting that the items have relatively high internal consistency since an acceptable value must lie between 0.70 and 0.90 (Tavakol \& Dennick, 2011).To observe content validity, the questionnaire was structured in such a way that the questions posed were clearly articulated and directed. All statements were formulated to eliminate the possibility of misinterpretations. This was followed by a pre-tested administered to 20 students who were excluded from participating in the main study. The identified amendments were made to ensure the simplicity and clarity of some questions, making it fully understandable to the participants.

Table 1: Cronbach Alpha

\begin{tabular}{|l|c|c|}
\hline Category & Number of items & Cronbach alpha \\
\hline Personal Adaptation & 5 & 0.624 \\
\hline Pedagogic Continuity & 10 & 0.681 \\
\hline Curriculum Continuity & 6 & 0.612 \\
\hline Performance Continuity & 6 & 0.511 \\
\hline Continuity Supportive Mechanisms & 6 & 0.503 \\
\hline Overall Questionnaire & 33 & 0.79 \\
\hline
\end{tabular}

Although the internal consistency shows that all the items in the questionnaire measure the same construct and are well connected, the inter-relatedness of the items in the identified categories of perspectives fall off the cut level of 0.7. This implies that the test items are not unidimensional do not appropriately measure the same construct. However Tavakol \& Dennick (2011) explained that such observations can be attributed to the small number of test items in the categories. Thus the small number of test items violated the assumption of tau-equivalence and underestimate reliability.

\section{Results and Discussions}

\subsection{Response rate}

A follow up of the questionnaires showed a good response rate from the research participants. Most of these concerns could be classified under five distinct headings: personal adaptability, pedagogic continuity, curriculum continuity, performance continuity and continuity supportive mechanisms.

Table 2: Demographic variables

\begin{tabular}{|c|c|c|c|}
\hline \multicolumn{2}{|c|}{ Variable } & Frequency & Percentages (\%) \\
\hline \multirow{2}{*}{ Gender } & Male & 26 & 43.3 \\
\cline { 2 - 4 } & Female & 34 & 56.7 \\
\hline \multirow{2}{*}{ Age } & $11-13$ years & 33 & 55 \\
\cline { 2 - 4 } & $14-16 y e a r s$ & 27 & 45 \\
\hline \multirow{3}{*}{ Home Language } & Sepedi & 40 & 66.7 \\
\cline { 2 - 4 } & Tshivenda & 12 & 20 \\
\cline { 2 - 4 } & Xitsonga & 2 & 3.3 \\
\cline { 2 - 4 } & Other & 6 & 10 \\
\hline
\end{tabular}

Respondents' demographic data shows that 26 (43.4\%) were males and 34(56.7\%) were females. The majority 33(55\%) of the participants were in the 11-13 years age category. The study was dominated by Sepedi speaking participants 40(66.7\%) while 14(23.3\%) spoke Tshivenda and Xitsonga. 


\subsection{Adaptation to secondary school}

Table 3: Descriptive Statistics: Students Adaptation

\begin{tabular}{|c|c|c|c|c|c|c|}
\hline$\underset{\underline{\Phi}}{\underline{E}}$ & & 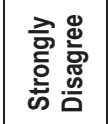 & 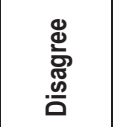 & 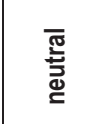 & $\begin{array}{l}\text { むँ } \\
\text { क्ष }\end{array}$ & 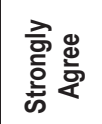 \\
\hline & A : Adaptation & \multicolumn{5}{|c|}{ Frequency and Percentages) } \\
\hline & It takes time to adapt to secondary school mathematics curriculum & $2(3.3)$ & $9(15.0)$ & $8(13.3)$ & $17(28.3)$ & $24(40.0)$ \\
\hline & I struggle to cope with different subjects and doing homework on time. & $4(6.7)$ & $11(18.3)$ & $7(11.7)$ & 14(23.3) & $24(40.0)$ \\
\hline 3. & There is a lot of pressure of work from different subject teachers & $9(15)$ & $17(28.3)$ & 12(20.0) & $12(20.0)$ & 10(16.7) \\
\hline 4. & I have problems in adjusting to several teachers who teach in different subjects. & $10(16.7)$ & $7(11.7)$ & $15(25.0)$ & $15(25.0)$ & 13(21.7) \\
\hline & $\begin{array}{l}\text { My interest and liking for mathematics decreases during the transition from primary to secondary } \\
\text { school. }\end{array}$ & $7(11.7)$ & $7(11.7 .0)$ & $3(5.0)$ & $8(13.3)$ & $35(58.3)$ \\
\hline
\end{tabular}

The results table 3 show students' responses to the various experiences during the transition from primary to secondary school. Forty-one (41) (68.3\%) confirmed that it takes time for them to adapt to secondary school mathematics curriculum. The results also indicate that 66(63.3\%) agreed that they struggle to cope with different subjects and doing homework on time. Another notable feature emerging from the results is the decrease in interest and liking for mathematics during the transition from primary to secondary school. This was confirmed by 43(72.6\%) who expressed concern over their dip in mathematics performance during the transition phase. These findings concur with Attard (2010) and McGee et al. (2003) who noted that difficulties during the transition phase can lead to disengagement, negative attitudes towards school, reduced self-confidence, and reduced levels of motivation in mathematics.

\subsection{Pedagogical continuity}

Table 4: Descriptive Statistics: Pedagogical Continuity

\begin{tabular}{|c|c|c|c|c|c|c|}
\hline 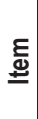 & & 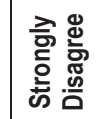 & 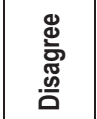 & 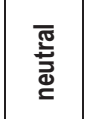 & 迹 & 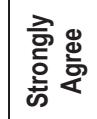 \\
\hline & B : Pedagogy & \multicolumn{5}{|c|}{ Frequency and Percentages) } \\
\hline 6. & Teachers take too long to realise and acknowledge my strength and weakness in mathematics. & $1(1.7)$ & $4(6.7)$ & $7(11.7)$ & $10(16.7)$ & $38(63.0)$ \\
\hline 7. & The time allocated for a mathematics period per day is adequate & $20(33.3)$ & 13(21.7) & $3(5.0)$ & $12(20.0)$ & $12(20.0)$ \\
\hline 8. & I am afraid that I may not rise up to my academic performance at grade 7 . & 19(31.7) & $11(18.3)$ & $5(8.3)$ & $13(21.7)$ & $12(20.0)$ \\
\hline 9. & There is adequate pedagogical continuity from primary to secondary school. & $14(23.3)$ & $16(26.7)$ & $4(6.7)$ & $13(21.7)$ & $13(21.7)$ \\
\hline 10. & There are differences in how my former and current mathematics and teacher explain concepts. & $17(28.3)$ & 15(25.0) & $7(11.7)$ & $10(16.7)$ & $11(18.3)$ \\
\hline 11. & The teaching and learning methods suit my academic needs & $16(26.7)$ & 11(18.3) & $3(5.0)$ & 13(21.7) & $17(28.3)$ \\
\hline 12. & My grade 7 teacher was more patient than my new secondary school teacher. & $12(20.0)$ & $10(16.7)$ & $5(8.3)$ & $18(30)$ & $15(25)$ \\
\hline 13. & f feel free to participate in secondary school mathematics class. & $16(26.7)$ & $13(21.7)$ & $1(1.7)$ & 17(28.3) & 13(21.7) \\
\hline 14. & $\begin{array}{l}\text { My secondary school mathematics teacher uses teaching and learning aids to enhance my } \\
\text { understanding. }\end{array}$ & 19(31.7) & $15(25.0)$ & $2(3.3)$ & $13(21.7)$ & $11(18.3)$ \\
\hline & $\begin{array}{l}\text { Secondary school mathematics teachers encourage students to compete for achievement recognition. I } \\
\text { appreciate being taught by mathematics specialists. }\end{array}$ & $15(2$ & & $8(13.3)$ & $12(20.0)$ & $10(16.7)$ \\
\hline
\end{tabular}

Coming to issues related to pedagogy, results indicate the majority of students (48 (80\%)) confirmed that teachers take too long to realise and acknowledge their strengths and weaknesses in mathematics and align their teaching and learning pace accordingly. Respondents 30(50\%) also indicated that there is inadequate pedagogical continuity from primary to secondary school. This contradicts their expectations since they hold the view that secondary school teachers are expertisees in their fields of specialisation. These students' concerns were also observed in a study conducted by Evangelou (2008) who noted that there is little pedagogical continuity from primary to secondary school. However the same respondents indicated that there were no significant differences in the way their former and current mathematics teachers explain concepts. Another notable difference in pedagogy is the use of teaching and learning aids, 34(56.7\%) of the respondents indicated that their secondary school mathematics teachers rarely use teaching and learning aids to enhance students' understanding. A number of researchers have argued that learning objects, if carefully selected, have a considerable potential to aid student learning (Kay \& Knaack, 2008; Nurmi \& Jaakkola,2006). Thus such a sudden shift 
from concrete learning to abstract learning in mathematics presents some form of pedagogic discontinuity.

\subsection{Mathematical content Continuity}

Table 5: Descriptive Statistics: Students Adaptation

\begin{tabular}{|c|c|c|c|c|c|c|}
\hline \begin{tabular}{|l}
$\mathbf{E}$ \\
Ф્
\end{tabular} & & 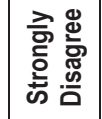 & 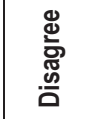 & 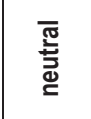 & 浐 & 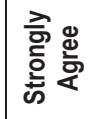 \\
\hline & C : Mathematics Content & \multicolumn{5}{|c|}{ Frequency and Percentages) } \\
\hline & The content coverage pace at secondary school suits my academic needs & $44(73.3)$ & $12(20.0)$ & $3(5.0)$ & $1(1.70)$ & $0(00.0)$ \\
\hline & $\begin{array}{l}\text { My knowledge of mathematics at primary school helps to understand new concepts at secondary } \\
\text { school. }\end{array}$ & $34(56.7)$ & $17(28.3)$ & $2(3.3)$ & $3(5.0)$ & $4(6.7)$ \\
\hline & There is adequate content continuity from primary to secondary school. & 13(21.7) & 7(11.7) & 7(11.7) & $8(13.3)$ & $25(41.7)$ \\
\hline & The mathematics content at grade 8 is a continuation of what we have been doing at grade 7 . & $30(50.0)$ & $17(28.3)$ & $8(13.3)$ & 2(3.3.) & $3(5.0)$ \\
\hline & $\begin{array}{l}\text { The level of difficulty in mathematics has increased and I have to know many concepts in a short space } \\
\text { of time. }\end{array}$ & $20(33.3)$ & $20(33.3)$ & $10(16.7)$ & $6(10.0)$ & $4(6.7)$ \\
\hline & $\begin{array}{l}\text { Secondary school mathematics teachers are impatient with slow learners and are not available for } \\
\text { individual attention. }\end{array}$ & 48.3) & $22(36.7)$ & $6(10.0)$ & $1(1.7)$ & 2(3.3) \\
\hline
\end{tabular}

Respondents indicated that the content coverage pace at secondary school is too fast and there are many aspects to be covered over a short space of time. The majority of the respondents $56(93.3 \%)$ indicated that they cannot cope with the pace at which mathematical content is covered at secondary school level. Respondents, 51(85\%) indicated that their background knowledge of mathematics from primary school is inadequate to help them to understand new concepts at secondary school. These findings concur with Howe and Val Richards (2011) who observed that students' shallow background knowledge of mathematics causes them to develop mathematical anxiety. Mathematical anxiety has detrimental effects on students' cognitive processes. It disrupts students' cognitive systems that enable them to store and process information concurrently.

\subsection{Academic achievement}

Table 6: Descriptive Statistics: Academic Achievement

\begin{tabular}{|c|c|c|c|c|c|c|}
\hline$\underset{\Phi}{\mathbb{\Phi}}$ & & 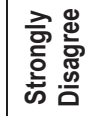 & 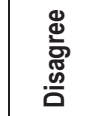 & $\begin{array}{l}\text { 퓬 } \\
\text { 离 }\end{array}$ & ֻँ & 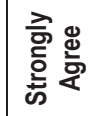 \\
\hline & D : Academic Achievement & \multicolumn{5}{|c|}{ Frequency and Percentages) } \\
\hline 22. & Secondary school teachers often disregard previous experience or achievement from grade 7 & $33(55)$ & $16(26.7)$ & $5(8.3)$ & $3(5.0)$ & $3(5.0)$ \\
\hline 23. & Pupils need to be held more responsible for their learning at secondary school. & $1(1.7)$ & $2(3.3)$ & $9(15.0)$ & $9(15.0)$ & $39(65)$ \\
\hline 24. & Grade 7 mathematics provides a good foundation for understanding grade 8 mathematics & $6(10.0)$ & $22(36.7)$ & $24(40.0)$ & $7(11.7)$ & $1(1.7)$ \\
\hline 25. & Do / did you experience academic dips as a result of the movement from primary to secondary school & $18(30.0)$ & $14(23.3)$ & $13(21.7)$ & $5(8.3)$ & $10(16.7)$ \\
\hline 26. & My academic performance suddenly changed after moving to secondary school. & $13(21.7)$ & $22(36.7)$ & $11(18.3)$ & $8(13.3)$ & $6(10.0)$ \\
\hline 27. & My confidence in mathematics has increased as a result of revisiting topics covered in prima & $20(33.3)$ & $18(30)$ & $11(18.3)$ & $2(3.3)$ & 9(15.0) \\
\hline
\end{tabular}

Respondents indicated that secondary school teachers acknowledge previous experience or achievement from primary school. Forty-nine (81.7\%) confirmed that their achievement prior to secondary school was acknowledged. The respondents also confirmed the shift of the responsibility for learning from the teacher to the learner. Thirty-two (53.3\%) respondents indicated that they experienced academic dips as a result of the transition from primary to secondary school. These findings are in line with previous research around the transition from primary to secondary schooling conducted by McGee et al. (2003) who argued that some level of achievement loss during the transition to secondary is unavoidable. 


\subsection{School support structures}

Table 7: Descriptive Statistics: School support structures

\begin{tabular}{|c|c|c|c|c|c|c|}
\hline $\begin{array}{c}\underline{E} \Phi \\
\Phi\end{array}$ & & 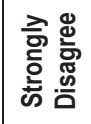 & 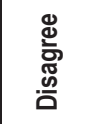 & 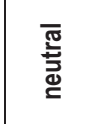 & 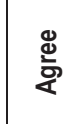 & 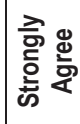 \\
\hline & C : School Support & \multicolumn{5}{|c|}{ Frequency and Percentages) } \\
\hline 28. & The school has structures in place to support newly recruited students. & $27(45)$ & $22(36.7)$ & $8(13.3)$ & $0(00.0)$ & $3(5.0)$ \\
\hline 29. & The orientation offered by the school (if any) helps to adjust to the secondary school system. & 22(36.7) & $20(33.3)$ & $15(25.0)$ & $2(3.30)$ & $1(1.7)$ \\
\hline 30. & $\begin{array}{l}\text { The changing of teachers for the different subjects has affected my personal academic relationships with } \\
\text { the teachers. }\end{array}$ & $30(50.0)$ & 19(31.7) & $10(16.7)$ & $0(0.00)$ & $1(1.7)$ \\
\hline 31. & My mathematics teacher provides for a smooth transition and continuity from primary to secondary school. & 20(33.3) & 21(35.0) & $11(18.3)$ & $4(6.7)$ & $4(6.7)$ \\
\hline 32. & My secondary school mathematics teacher provides individual attention to the learners. & $14(23.3)$ & $25(41.7)$ & $11(18.3)$ & $7(11.7)$ & $3(5.0)$ \\
\hline 33. & $\begin{array}{l}\text { I am free to consult my secondary school mathematics teacher if I experience some challenges in } \\
\text { mathematics. }\end{array}$ & $15(25.0)$ & 23(38.3) & $11(18.3)$ & $7(11.7)$ & $4(11.4)$ \\
\hline
\end{tabular}

The majority 59 (98.3\%) of the respondents indicated the sampled schools have no structures in place to support newly recruited students. They also agreed that the orientation offered by the schools is not enough for one to adjust to the secondary school system. Jindal-Snape, Douglas, Topping, Kerr and Smith (2006) recommended that primary schools should complete a transfer information form for every child detailing the child's special educational needs. These details will provide teachers with sufficient background information about the learners they are about to engage.

\subsection{T-tests for Means}

Table 8: T-test

\begin{tabular}{|c|c|c|c|c|c|c|}
\hline & \multicolumn{6}{|c|}{ Test Value $=0$} \\
\hline & \multirow{2}{*}{$\mathrm{t}$} & \multirow{2}{*}{$d f$} & \multirow{2}{*}{ Sig. (2-tailed) } & \multirow{2}{*}{ Mean Difference } & \multicolumn{2}{|c|}{ 95\% Confidence Interval of the Difference } \\
\hline & & & & & Lower & Upper \\
\hline Gender & 24.284 & 59 & .000 & 1.5667 & 1.438 & 1.696 \\
\hline Adaptation & 37.898 & 59 & .000 & 3.1867 & 3.018 & 3.355 \\
\hline Pedagogical Continuity & 39.464 & 59 & .000 & 2.6167 & 2.484 & 2.749 \\
\hline Maths Content Continuity & 31.411 & 59 & .000 & 2.0639 & 1.932 & 2.195 \\
\hline Performance Continuity & 32.845 & 59 & .000 & 2.7056 & 2.541 & 2.870 \\
\hline Teachers' Support & 25.041 & 59 & .000 & 2.0722 & 1.907 & 2.238 \\
\hline
\end{tabular}

The research also hypothesised that there are significant differences in experiences between males and females. To test whether this is the case, a t-test was also conducted. Results for the test are shown in table 8 ( $\mathrm{df}=59, \mathrm{t}=24.284$, $p=0.00$ ). Therefore, a null hypothesis was rejected since $p<0.05$. Therefore we conclude that there are significant gender differences in the ways males and females perceive the transition from primary to secondary school. The results in table 4 also indicate there significant differences in continuity variables such as pedagogy ( $\mathrm{df}=59, t=37.898, p=0.00$ ), content $(d f=59, t=39.464, p=0.00)$, performance $(d f=59, t=32.845, p=0.00)$ and teachers' support $(d f=59, t=25.041, p=0.00)$. All the p-values are less than 0.05 ; hence we conclude that there are gender differences in students' experiences in mathematics during the transition from primary school to secondary school. This is consistent with findings from McGee, Ward, Gibbons \& Harlow who found that transition appears to have a positive effect, particularly on the performance of boys, in maths and science. The findings are also consistent with Wright's (2000) who observed that girls who are most negatively affected by transition. 


\subsection{Analysis of variance (ANOVA)}

Table 9: Anova

\begin{tabular}{|ll|c|c|c|c|c|}
\hline & & Sum of Squares & $\mathrm{df}$ & Mean Square & $\mathrm{F}$ & Sig. \\
\hline \multirow{3}{*}{ Adaptation } & Between Groups & 1.418 & 3 & .473 & 1.121 & .348 \\
& Within Groups & 23.611 & 56 & .422 & \\
& Total & 25.029 & 59 & & & \\
\hline \multirow{3}{*}{ Pedagogy } & Between Groups & .741 & 3 & .247 & .934 & .430 \\
& Within Groups & 14.822 & 56 & .265 & & \\
\hline \multirow{3}{*}{ Maths Content } & Total & 15.563 & 59 & & & \\
& Between Groups & .372 & 3 & .124 & .466 & .707 \\
& Within Groups & 14.910 & 56 & .266 & & \\
Academic performance & Total & 15.283 & 59 & & & \\
& Between Groups & 1.468 & 3 & .489 & 1.215 & .313 \\
& Within Groups & 22.553 & 56 & .403 & & \\
\hline \multirow{3}{*}{ Teachers' Support } & Total & 24.020 & 59 & & & .616 \\
& Between Groups & .774 & 3 & .258 & .608 \\
& Within Groups & 23.469 & 56 & .419 & & \\
\hline
\end{tabular}

An analysis of variance test was conducted to test for language backgrounds differences in terms of students' experiences to Adaptation, Pedagogy, Content, performance and teacher support. The results for the test are shown in table 9 above. The results in table 9 indicate there are no significant differences in continuity variables: adaptation $(d f=3, d f=56, F=1.121, p=0.348$ ), pedagogy ( $d f=3, d f=56, F=0.934, p=0.430)$, content ( $d f=3, d f=56, F=0.466, p=0.707)$, performance ( $d f=3, d f=56, F=1.215, p=0.313$ ) and teachers' support $(d f=3, d f=56, F=0.616, p=0.608)$. All the $p$-values are more than 0.05 , we fail to reject the null hypothesis and conclude that there are no language background differences in students' experiences in mathematics during the transition from primary school to secondary school. These findings are consistent with Draghici (2001) who furnished evidence which indicates some small effects of children's academic development is associated with language background neighbourhood.

\subsection{Teachers' strategies for sustaining continuity during transition}

Table 10: Teachers' strategies for sustaining continuity during transition

\begin{tabular}{|c|c|c|c|c|c|c|}
\hline \multirow[t]{2}{*}{$\begin{array}{l}\stackrel{\Xi}{\mathbf{E}} \\
\stackrel{ \pm}{ \pm}\end{array}$} & & 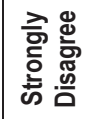 & 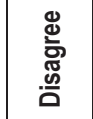 & 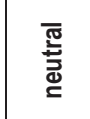 & 浐 & 言㐫 \\
\hline & & \multicolumn{5}{|c|}{ Frequency(Percentages) } \\
\hline 1. & $\begin{array}{l}\text { It is important to create strong primary -secondary teachers' ties to ensure a smooth transition from } \\
\text { feeder schools to receiving schools. }\end{array}$ & $1(10.0)$ & $1(10.0)$ & $0(0.00)$ & $|5(50.0)|$ & $3(30.0)$ \\
\hline 2. & $\begin{array}{l}\text { It is important for the secondary school mathematics teachers to have the primary school mathematics } \\
\text { syllabus, textbooks and other supporting curriculum documents. }\end{array}$ & $7(70.0)$ & $2(20.0)$ & $0(0.00)$ & $1(10.0)$ & $0(0.00)$ \\
\hline 3. & Students' prior knowledge of must be established before embarking on a new topic. & $0(0.00)$ & $0(0.00)$ & $(0.00)$ & $2(20.0)$ & $8(80.0)$ \\
\hline 4. & Intervening measures should be in place to support the & $0(0.00)$ & $1(10.0)$ & $3(0.00)$ & $3(30.0)$ & $3(30.0)$ \\
\hline 5. & ith primary schools that can help learners to ease their worries & $1(10.0)$ & 2(0.00) & $0(0.00)$ & $3(30.0)$ & $4(40.0$ \\
\hline 6. & $\begin{array}{l}\text { It is important for teachers to help students to prepare by addressing worries, reassuring and } \\
\text { encouraging them, explaining what to expect and how secondary school works, and by giving advice } \\
\text { and tips on how to cope at their new school. }\end{array}$ & $0(0.00)$ & $1(10.0)$ & $1(10.0)$ & $3(30.0)$ & $5(50.0$ \\
\hline & $\begin{array}{l}\text { Continuity of curriculum: secondary schools should have sustained linking arrangements focused on } \\
\text { the learning progression of individual pupils. }\end{array}$ & $1(10.0)$ & $2(20.0)$ & $2(20.0)$ & $|1(10.0)|$ & $4(40.0$ \\
\hline & $\begin{array}{l}\text { The school must put systems in place to deal with at-risk pupils who need intervention prior to } \\
\text { transition. }\end{array}$ & $3(30.0)$ & $2(20.0))$ & $1(10.00)$ & $3(30.0)$ & $1(10$ \\
\hline 9. & Pupils need to be guided so that they do not treat mathematics as an anxiety producing subject. & $0(0.00)$ & $1(10.0)$ & $3(30.0)$ & $5(50.0)$ & $1(10$. \\
\hline 10. & The curriculum should have bridging topics in order to alleviate the problem of curriculum discontinuity. & $0(0.00)$ & $1(10.0)$ & $3(30.0)$ & $3(30.0)$ & $3(30$. \\
\hline 11. & Pupils' academic attainment information supplied by primary schools is insufficient & $2(20.00)$ & $3(30.0)$ & $1(10.0)$ & $3(50.0)$ & $1(10$. \\
\hline 12. & $\begin{array}{l}\text { Public examinations results should be used to place learners into secondary schoo } \\
\text { to performance. }\end{array}$ & 0) & $1(10.0)$ & $1(10.0)$ & $|1(10.0)|$ & ) \\
\hline
\end{tabular}


Responses from grade 8 mathematics teachers are shown in table 10 above. Though the sample size was too small $(n=10)$, results from the table indicate that most teachers were positive about creating strong primary - secondary teachers' ties to ensure a smooth transition from feeder schools to receiving schools. There was a general consensus among the teacher respondents that students' prior knowledge and previous achievements of must be established before embarking on the secondary school mathematics curriculum. The same group of respondents recommended that students should sit for a public examination or entrance test and results from such tests should be used to place learners into secondary school streams according to subject performance. However, the respondents disagreed to the idea of having the primary school mathematics syllabus, textbooks and other supporting curriculum documents. This is in sharp contrast with Howe, Val Richards (2011) who suggested the need to establish what they referred to as 'bridging units' in order to induct primary school students to secondary school mathematics.

\section{Limitations}

The small sample size (4 schools and 60 learners and 10 teachers) of this study limits the generalizability of the findings, and caution must be taken when generalising the findings to other populations. A larger scale study involving a range of schools is required to further explore transition issues in South African schools. Future research in this area could be improved through longitudinal studies with larger samples.

\section{Conclusion and Recommendations}

This study highlighted the major challenges that students experience during the transition from primary to secondary school with special regard to mathematics learning. The study investigated students' experiences on five strands of transitions: adaptation, pedagogy, curriculum content, achievement and school intervention structures. Students indicated that it takes time to adapt to secondary school mathematics curriculum and most of them struggle to cope with different subjects and doing homework on time. Some students indicated that their interest and liking for mathematics decreases during the transition from primary to secondary school. Such perceptions of these specific aspects of transition should be taken into account when designing content for transition support programs, in order to cater for the specific concerns of students.Students also acknowledged experiencing changes in mathematics teaching and learning that resulted in limited engagement. It is therefore worth to note that such aspects of their experiences that should be focused upon and highlighted if any future improvements are to take place. Teachers should strive to work on building sound and positive academic relationships with the students. A positive pedagogical relationship includes a strong knowledge of how students learn and a strong content knowledge. If teachers are not well trained in mathematics pedagogy, this may not always occur. It can be argued that the apparent lack of appropriately qualified mathematics teachers could be a result of students' disengagement in mathematics. The use of more hands-on activities and concrete materials should continue at the lower secondary school levels when students are still making the transition from a concrete-manipulative state to abstract thought. Even though the structure of secondary school timetables makes the provision of such activities more difficult for teachers, it is probable that incorporation of such pedagogies would be of benefit during the transition period.The findings of this study on student performance during the transition from primary to secondary schooling indicated that learners experience a drop in academic achievement. This performance dip can be temporary or permanent. Students' attitudes towards mathematics often decrease over this period. Schools and grade 8 mathematics teachers need to measures in place to sustain students' academic competence.

\section{Recommendations}

Attention needs to be given to discontinuities in teaching approaches; the gap between pupils' expectations of secondary school and the reality; helping teachers develop strategies for helping students manage their own learning; giving pupils the opportunity to ask questions on aspects they do not understand, particularly relating to classroom learning, and flexible learning/teaching, which takes account of differences in pupils' preferred learning styles.It can also be argued the impacts of transition, pedagogy and teacher-student relationships may have implications for different student groups. Teachers should strive to work on building sound and positive academic relationships with the students. Repetition of the study in different contexts and further investigation of factors affecting engagement during the transition years would be of benefit in helping students maintain engagement in mathematics during the transition phase to secondary school. 


\section{References}

Adeyemo, D. A. (2005). The buffering effect of emotional intelligence on the adjustment of secondary school students in transition. Electronic Journal of Research in Educational Psychology, 6(2), 79-90.

Anderson, L. W., Jacobs, J., Schramm, S., \& Splittgerber, F. (2000). School transitions: beginning of the end or a new beginning. International Journal of Educational Research, 33(4), 325-339.

Attard, C. (2010). Students' Experiences of Mathematics during the Transition from Primary to Secondary School. Mathematics Education Research Group of Australasia. Sense Publishers: Rotterdam.

Attard, C. (2011). "My favourite subject is maths. For some reason no-one really agrees with me": student perspectives of mathematics teaching and learning in the upper primary classroom. Mathematics Education Research Journal, 23(3), 363-377.

Bangser, M. (2008). Preparing High School Students for Successful Transitions to Postsecondary Education and Employment. Issue Brief. National High School Centre.

Chauraya, M. (2008). Pupil's perceptions and their teacher's awareness of continuity in Mathematics instruction at primary-secondary transition phase in Gweru urban school in Zimbabwe. The Dyke, 3(2), 43-57.

Darlaston-Jones, D., Cohen, L., Drew, N., Haunold, S., Pike, L., \& Young, A. (2001). Addressing attrition: Why we need a unified approach to transition issues. In expanding horizons in teaching and learning. Proceedings of the 10th Annual Teaching Learning Forum (pp. 7-9).

De Vos, A. S., Delport, C. S. L., Fouché, C. B., \& Strydom, H. (2011). Research at grass roots: A primer for the social science and human professions. Pretoria: Van Schaik Publishers.

Evangelou, M. (2008). What makes a successful transition from primary to secondary school? British Journal of Educational Psychology, 81(20), 244-263.

Fabian H (2000) Small Steps to Starting School. International Journal of Early Years Education, 8(2):141-152

Fishman, S. M., \& McCarthy, L. P. (1998). John Dewey and the challenge of classroom practice. New York: Teachers College Press.

Galton, M. Gray, J.M. and Ruddock, J. (2003). Transfer and transitions in the middle years of schooling (7-14). Continuities and discontinuities in learning. Cambridge: Queen's Printer.

Ganeson, K. (2006). Students' lived experience of transition into high school: A phenomenological study. (Unpublished doctoral dissertation). Brisbane: Queensland University of Technology.

Gorwood, B. T. (1986). School transfer and curriculum continuity. London: Croom Helm.

Griebel, W., \& Berwanger, D. (2006). Transition from primary school to secondary school in Germany. International Journal of Transitions in Childhood, 2(6), 32-39.

Hardy, C. L., Bukowski, W. M., \& Sippola, L. K. (2002). Stability and change in peer relationships during the transition to middle-level school. The Journal of Early Adolescence, 22(2), 117-142.

Hawk, K., \& Hill, J. (2004).Transition traumas, traps, turning points and triumphs: Putting student needs first. Paper presented at The Way Forward for Secondary Education Conference, Wellington, New Zealand.

Jha, J., \& Kelleher, F. (2006). Boys' Underachievement in Education: An exploration in selected commonwealth countries. Vancouver: Commonwealth of Learning.

Jindal-Snape, D., \& Foggie, J. (2006). Moving stories: A research study exploring children/young people, parents and practitioners' perceptions of primary-secondary transitions. Report for Transitions Partnership Project. Dundee: University of Dundee

Kay, R., \& Knaack, L. (2008). Investigating the use of learning objects for secondary school mathematics. Interdisciplinary Journal of ELearning and Learning Objects, 4(1), 269-289.

La Paro, K. M., Pianta, R. C., Cox, M. J., \& Allen, J. (2000). Teachers' reported transition practices for children transitioning into kindergarten and first grade. Exceptional Children.

Mackenzie, E., McMaugh, A., \& O'Sullivan, K.A (2012). Perceptions of primary to secondary school transitions: Challenge or threat? Issues in Educational Research, 22(3), 298-314.

Marzano, R. J., Pickering, D., \& Heflebower, T. (2011). The highly engaged classroom. Centennial: Marzano Research Laboratory.

McGee, C., Ward, R., Gibbons, J., \& Harlow, A. (2003). Transition to secondary school: a literature review. A report to the Ministry of Education. Hamilton, University of Waikato, New Zealand.

Mirkhil, M. (2010). Important ingredients for a successful transition to school. International Research in Early Childhood Education, 1(1), 60-70.

Mizelle, N Hawk, K., \& Hill, J. (2004). B., \& Irvin, J. L. (2000). Transition from Middle School to High School. What Research Says. Middle School Journal, 31(5), 57-61.

Moroney, W., \& Stocks, C. (Eds.). (2005). Quality mathematics in the middle years. Adelaide: S.A.: AAMT.

Nardi, E., \& Steward, S. (2003). Is mathematics T.I.R.E.D? A profile of quiet disaffection in the secondary mathematics classroom. British Educational Research Journal, 29(3), 345-367

Nordqvist, M., Hall, A., \& Melin, L. (2009). Qualitative research on family businesses: The relevance and usefulness of the interpretive approach. Journal of Management and Organization, 15(3), 294.

Nurmi, S., \& Jaakkola, T. (2006). Promises and pitfalls of learning objects. Learning, Media and Technology, 31(3), $269-285$.

O'Donnell, V. L., \& Tobbell, J. (2007). The transition of adult students to higher education: legitimate peripheral participation in a community of practice. Adult Education Quarterly, 57(4), 312-328.

Parker, A. K., \& Neuharth-Pritchett, S. (2009). Calming rough waters: Teacher strategies for smoothing the transition to middle school. 
Childhood Education, 86(1), 20-26.

Petriwskyj, A., Thorpe, K., \& Tayler, C. (2005). Trends in construction of transition to school in three western regions, 1990-2004. International Journal of Early Years Education, 13(1), 55-69.

Powell, R., Smith, R., Jones, G., \& Reakes, A. (2006). Transition from primary to secondary school: Current arrangements and good practice in Wales. Final Report. Slough: NFER.

Rammala, M. S. (2009). Factors contributing towards poor performance of grade 12 learners at Manoshi and Mokwatedi High Schools (Doctoral dissertation). University of Limpopo.

Reay, D., \& Lucey, H. (2000). Children, school choice and social differences. Educational Studies, 26(1), 83-100.

Skovsmore, O. and Valero, P.: 2002, 'Democratic access to powerful mathematical ideas', in L.D. English (ed.), Handbook of International Research in Mathematics Education, Lawrence Erlbaum, Mahwah, NJ, pp. 383-408.

Tavakol, M., \& Dennick, R. (2011). Making sense of Cronbach's alpha. International journal of medical education, 2, 53-55.

Tilleczek, K. (2008). Building Bridges: Transitions from Elementary to Secondary School. Education Canada, 48(1), 68-71.

Tobbell, J., O'Donnell, V., \& Zammit, M. (2010). Exploring transition to postgraduate study: shifting identities in interaction with communities, practice and participation. British Educational Research Journal, 36(2), 261-278.

Ward, R., Gibbons, J., \& Harlow, A. (2004). Transfer from middle to secondary school: A New Zealand study. International Journal of Educational Research, 33(4), 365-374.

West, P., Sweeting, H., \& Young, R. (2010). Transition matters: pupils' experiences of the primary-secondary school transition in the West of Scotland and consequences for well-being and attainment. Research papers in education, 25(1), 21-50.

Wylie, C., Hodgen, E., \& Ferral, H. (2006). Completely Different Or a Bigger Version?: Experiences and Effects of the Transition to Secondary School: Evidence from the Competent Children, Competent Learners Project: Final Report to the Ministry of Education. New Zealand Council for Educational Research.

Zeedyk, M. S., Gallacher, J., Henderson, M., Hope, G., Husband, B., \& Lindsay, K. (2003). Negotiating the transition from primary to secondary school perceptions of pupils, parents and teachers. School Psychology International, 24(1), 67-79. 